Issued by Sandia National Laboratories, operated for the United States Department of Energy by Sandia Corporation.

NOTICE: This report was prepared as an account of work sponsored by an agency of the United States Government. Neither the United States Government nor any agency thereof, nor any of their employees, nor any of their contractors, subcontractors, or their employees, makes any warranty, express or implied, or assumes any legal liability or responsibility for the accuracy, completeness, or usefulness of any information, apparatus, product, or process disclosed, or represents that its use would not infringe privately owned rights. Reference herein to any specific commercial product, process, or service by trade name, trademark, manufacturer, or otherwise, does not necessarily constitute or imply its endorsement, recommendation, or favoring by the United States Government, any agency thereof, or any of their contractors or subcontractors. The views and opinions expressed herein do not necessarily state or reflect those of the United States Government, any agency thereof, or any of their contractors.

Printed in the United States of America. This report has been reproduced directly from the best available copy.

Available to DOE and DOE contractors from Office of Scientific and Technical Information

P.O. Box 62

Oak Ridge, TN 37831

Prices available from (615) 576-8401, FTS 626-8401

Available to the public from

National Technical Information Service

U.S. Department of Commerce

5285 Port Royal Rd

Springfield, VA 22161

NTIS price codes

Printed copy: A03

Microfiche copy: A01

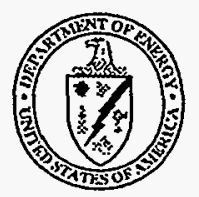




\section{DISCLAIMER}

Portions of this document may be illegible in electronic image products. Images are produced from the best available original document. 
SAND 98-2538

Unlimited Release

Printed December 1998

\title{
Development and Characterization of a New Epoxy Foam Encapsulant as an Ablefoam Replacement
}

\author{
Edward M. Russick \\ Sandia National Laboratories \\ P. O. 5800 \\ Albuquerque, NM 87185-0367 \\ Peter B. Rand \\ Innovative Technology \\ Albuquerque, NM 87112
}

\begin{abstract}
A new epoxy foam encapsulant, EF-AR10/20, has been developed at Sandia National Laboratories (SNL) as a replacement for Ablefoam ${ }^{\circledR}$, an epoxy foam encapsulant used in the W76 Arming, Fusing, and Firing (AF\&F) system. Since it contained toxic ingredients including a known carcinogen, Ablefoam ${ }^{\otimes}$ is no longer commercially available. It has been demonstrated by scanning electron microscopy (SEM) that the microstructure of the new epoxy foam is similar to that of Ablefoam ${ }^{\Theta}$. Mechanical properties of tensile and compressive strength, and tensile and compressive modulus, and thermal properties of glass transition temperature $\left(\mathrm{T}_{\mathrm{g}}\right)$, and coefficient of thermal expansion (CTE) have been measured for the new foam. Electrical properties of dielectric constant, dissipation factors, volume resistivity, and dielectric strength were also measured. These property measurements are comparable to those of Ablefoam ${ }^{\ominus}$. Development and characterization of the new foam will be discussed, and a comparison of mechanical, thermal, and electrical properties for the new epoxy foam and Ablefoam $^{\circledR}$ will be reported.
\end{abstract}




\section{Contents}

Introduction

Background

Epoxy foam development

Ablefoam ${ }^{\circledR}$ replacement

Foam properties

Foam morphology

Compressive properties

Tensile properties

Thermal properties

Electrical properties

W76 AF\&F redesign

Conclusions

Acknowledgements

References

\section{Figures}

1 Diglycidyl ether of bisphenol A epoxy resin

2 Typical cure reaction between an epoxy resin and an amine curing agent

3 SEM comparison of Ablefoam ${ }^{\circledR}$ (a) and the new epoxy foam patch (b)

4 Thermocouple access holes cut in Ablefoam ${ }^{\circledR}$ on the W76 AF\&F

5 SEM comparison of $20 \mathrm{lb} / \mathrm{ft}^{3} \operatorname{Ablefoam}^{\circledR}(\mathrm{a}), \mathrm{EF}-\mathrm{AR} 20\left[20 \mathrm{lb} / \mathrm{ft}^{3}\right]$ (b), and EF-AR10 $\left[10 \mathrm{lb} / \mathrm{ft}^{3}\right]$ (c)

6 Plot of maximum compressive strength versus density for EF-AR10/20 and $\mathrm{Ablefoam}^{\circledR}$

7 Plot of ultimate tensile strength versus density for EF-AR10/20 and Ablefoam

8 Plot of shear and loss modulus versus temperature data for a sample of EF-AR20 $\left(20 \mathrm{lb} / \mathrm{ft}^{3}\right)$

9 Parts machined from the new epoxy foam for a prototype of the new W76 AF\&F design

\section{Tables}

1 Epoxy patch formulation used for W76 AF\&F thermal testing

2 Formulation for Ablefoam ${ }^{\circledR}$ Replacement EF-AR20 $\left(\rho=20 \mathrm{lb} / \mathrm{ft}^{3}\right)$

3 Formulation for Ablefoam ${ }^{\circledR}$ Replacement EF-AR10 $\left(\mathrm{r}=10 \mathrm{lb} / \mathrm{ft}^{3}\right)$

4 Compressive strength and modulus of EF-AR10/20 and Ablefoam ${ }^{\circledR}$

5 Ultimate tensile strength and modulus of EF-AR10/20 and Ablefoam ${ }^{\odot}$

6 Coefficient of thermal expansion $\left(x 10^{-6} /{ }^{\circ} \mathrm{C}\right)$ for EF-AR $10 / 20$ and Ablefoam ${ }^{\circledR}$

7 Dielectric constants for EF-AR10/20 and Ablefoam ${ }^{\circledR}$

8 Dissipation factors for EF-AR $10 / 20$ and Ablefoam ${ }^{(3)}$

9 Volume resistivity (ohm-cm) data for EF-AR10/20 and Ablefoam ${ }^{\circledR}$ 


\section{Development and Characterization of a New Epoxy Foam Encapsulant as an Ablefoam Replacement}

\section{Introduction}

Rigid polymeric foams (e.g., epoxy, polyurethane) have been used as encapsulants in a variety of weapon systems in the nuclear stockpile. Ablefoam ${ }^{\circledR}$, a product of Ablestick Corp., was an epoxy foam encapsulant used in the W76 AF\&F that comprises a major portion of the enduring weapons stockpile. Ablefoam ${ }^{\circledR}$ contained several toxic components, including methylene dianiline (MDA), an epoxy curing agent, which is a known carcinogen. The existing AF\&F's in the W76 were not designed to be maintainable and cannot be returned to the stockpile after being tested for reliability and aging effects. Currently, a redesign of the W76 AF\&F, a part of the block upgrade program, is underway which would allow for maintenance, repair, and upgrading of components in the unit. Since Ablefoam ${ }^{\circledR}$ is no longer commercially available, a new foam encapsulant is required.

Foam encapsulants have some advantages over solid encapsulants due to their relative density ${ }^{1}$ (i.e., porosity). One advantage of lower density is weight savings, which may be important especially in weapons applications. Secondly, a polymeric foam has a lower bulk modulus compared to a solid encapsulant, which makes the material more compressible and less likely to crack under internal stresses which may occur due to thermal cycling. Ablefoam ${ }^{\circledR}$ was originally chosen for the W76 AF\&F in part because it possessed good mechanical, thermal, and electrical properties ${ }^{2}$, yet was found to be brittle enough that the foam could be mechanically removed (i.e., chipped away) from the encapsulated component to allow for testing and analysis of the unit. Polyurethane foams tend to be considerably more difficult to remove $^{3}$. To retain the desirable materials properties and mechanical removability present in Ablefoam $^{(}$, an effort began to develop a new epoxy foam encapsulant as an Ablefoam ${ }^{\circledR}$ replacement for the W76 AF\&F upgrade.

The epoxy foam formulation described in this report has been designed to make rigid epoxy foam for use as a foam encapsulant for electrical or electromechanical components and instrumentation that require protection against mechanical shock or vibrational forces. In fact, it may be suitable for other applications that require a rigid epoxy foam that must be foamed in place. The epoxy foam may also be used as a patch for existing foam encapsulation that has been partially removed to allow for the repair, replacement, or retrofitting of components. Foams produced with this formulation have uniform cellular morphology with nominal cell sizes in the range of $100-300$ micrometers at $20 \mathrm{lb} / \mathrm{ft}^{3}(0.321 \mathrm{~g} / \mathrm{cc})$ density. While virtually all cured epoxy systems are exothermic processes (i.e., evolves heat), this foam formulation has a sufficiently low exotherm so as to allow for the casting of large samples with significant thicknesses without burn out of the foam due to the generation of internal heat. The formulation is free of MDA, and based on current toxicological information, contains no carcinogenic agents.

The new epoxy foams are referred to as EF-AR10/20 (Epoxy Foam - Ablefoam Replacement at 10 to $20 \mathrm{lb} / \mathrm{ft}^{3}$ nominal densities). The foams may also be referred to individually as EF-AR10 at $10 \mathrm{lb} / \mathrm{ft}^{3}$ nominal density and EF-AR20 for $20 \mathrm{lb} / \mathrm{ft}^{3}$ nominal density. 


\section{Background}

In the development of an epoxy foam, it is helpful to understand the epoxy curing process and the materials required for making a foamed epoxy. The following description of epoxy chemistry can be found in a number of sources ${ }^{4,5,6,}$. Cured epoxies, solid or foamed, are formed by crosslinking reactions between an epoxy resin and a curing agent which create a three-dimensional covalent bond network. There are numerous commercially available epoxy resins and curing agents. ${ }^{8}$. A type of epoxy resin that is commonly used, is diglycidyl ether of bisphenol A (DGEBPA), such as Epon 828, a product of Shell Corporation. A typical DGEBPA chemical structure is depicted in Figure 1. The addition of a curing agent causes the liquid resin to cure or harden into a rigid cross-linked polymer. When the resin is intimately mixed with a stoichiometric amount of a curing agent containing labile hydrogen atoms, the epoxy ring opens and reacts with the curative. A simplified representation of an epoxy cure reaction is shown in Figure 2. Most cured epoxy foams are produced using one of three types of curing agents, which are amines, polyphenols, and anhydrides. Cure is achieved by polyaddition with no by-product formation, and the cure reaction between epoxy resins and curatives is exothermic which, in some cases, can evolve a considerable amount of heat. Control of evolved heat can be an important consideration in an epoxy foam. Because a foamed epoxy is an insulating material (i.e., low thermal conductivity), heat unable to escape from the center of a sufficiently large sample may actually char or burn the interior of the foam.

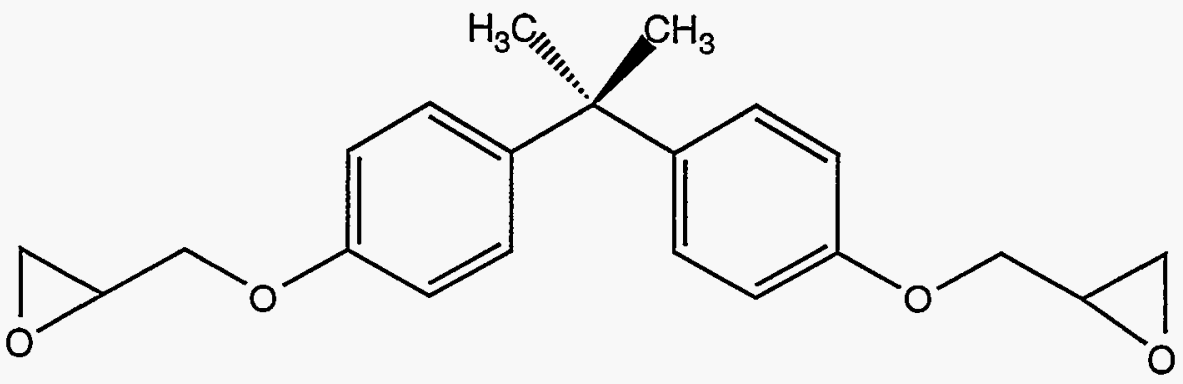

Figure 1: Diglycidyl ether of bisphenol A epoxy resin.

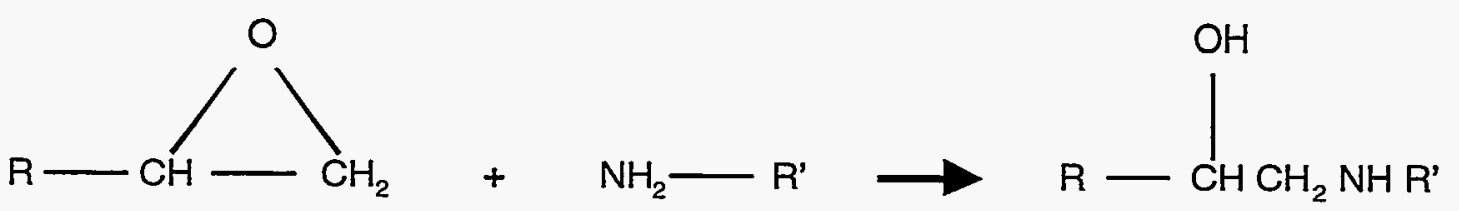

Figure 2: Typical cure reaction between an epoxy resin an amine curing agent.

Aside from a resin and curing agent, other constituents ${ }^{5}$ used to make an epoxy foam are a foaming agent, a surfactant, and a filler/nucleating agent. Since epoxies normally react with the curing agent without evolving volatiles, the addition of a foaming agent is required. The foaming agent may be a chemical, which thermally decomposes and evolves gas due to the heat of the exothermic epoxy reaction, or a physical agent, which simply vaporizes at its boiling temperature to liberate gas. Chemical blowing agents ${ }^{9}$ include ammonium carbonate, sodium bicarbonate, and sulfonyl hydrazide. Physical blowing agents ${ }^{9}$ include liquid solvents such as toluene, fluorocarbons (FCs), chlorofluorocarbons (CFCs), and hydroclorofluorocarbons (HCFCs). 
Surfactants are used in epoxy foams to promote foaming and stabilization of the subsequent cellular structure. The surfactants used in polyurethane foam systems, such as silicone-based surfactants, are the same ones generally used in epoxy foams. Benning ${ }^{10}$ notes that cell structure can be greatly affected by the surfactant, which in turn influences the properties of the resultant foam.

Fillers are added to epoxy foam formulations for a variety of reasons including lowering cost, adding color, reducing exotherms, and controlling shrinkage rates. Fillers in the form of fine particles (e.g., carbon black, fumed silica) may also serve as nucleating agents. Small particles provide sites for heterogeneous nucleation which allow for initiation and subsequent growth of foam cells ${ }^{4,11}$. In heterogeneous nucleation, gas molecules driven by super-saturation preferentially form nucleation sites on the solid/fluid interfaces of the nucleating agent. The ultimate cell size is determined by other factors including the exotherm, the rate of cure, the amount of blowing agent, and interactions between the epoxy and surfactant.

\section{Epoxy Foam Development}

There are several important parameters that must be considered in the development of a foam with a desirable cellular structure. First, the rheology of the epoxy mixture during the rise of the foam is vitally important. As the epoxy and curing agent cross-link and cure, the liquid becomes more viscous. The viscosity increase is necessary to retain the cell structure created during the rise of the foam. An epoxy that does not become sufficiently viscous to maintain a cellular structure during the rise of the foam will coalesce and collapse. An epoxy that becomes extremely viscous and gels too early may prematurely terminate the foam rise, not allowing for full expansion. A second important processing parameter closely related to foam rheology is the epoxy cure rate, which is largely dependent on the processing temperature. A very fast reacting epoxy-curative system with a large exotherm may result in a cure rate, which does not allow sufficient processing time for the foam to rise. Furthermore, an excessive amount of heat from a large exotherm could result in burn out of the interior regions of the foam. Conversely, an extremely slow reacting epoxy may not become viscous and gel within an appropriate amount of time to establish a cellular structure during the foam rise, requiring addition of external heat or a reaction accelerator to increase the cure rate. Other processing parameters which affect epoxy foam quality and cell structure are surface tension and cell nucleation. Surfactant is added at an appropriate level to control the surface tension of the fluid. As has already been established, the surfactant can have a significant influence on cell size and foam morphology. The addition of fine particulates such as carbon black or fumed silica can be added to facilitate the nucleation of a great number of small foam pores.

Initially, an epoxy foam formulation was developed exclusively for use as a patch for Ablefoam $^{\circledR}$ in the W76. The foam patch was required for radiant heat testing performed on the W76 AF\&F to simulate the effects of a fire on the unit. The requirements for the epoxy patch were that it match the density of the Ablefoam ${ }^{\otimes}$ encapsulant $\left(20 \mathrm{lb} / \mathrm{ft}^{3}\right)$ that it have a similar foam morphology. The epoxy patch formulation is contained in Table 1 . Two resins were utilized in the epoxy patch formulation. Shell Epon 828 is probably the most common DGEBPA resin, and Shell Epon 8121 is a highly reactive epoxy polyacrylate resin which can be added at an appropriate amount to accelerate the cure reaction to a desired degree. It was found that using a dual resin system allowed for fine-tuning the reaction to attain a reasonable balance of foam expansion and desirable cell structure. In developmental molding experiments, it was found that the $20 \mathrm{lb} / \mathrm{ft}^{3}$ density of $\mathrm{Ablefoam}{ }^{\circledR}$ could be achieved with the epoxy foam patch formulation. By scanning electron microscopy (SEM), it was found that the 
epoxy foam patch had a reasonable foam morphology with pore sizes of approximately 200 $\mu \mathrm{m}$. A comparison of foam structures of Ablefoam ${ }^{\circledR}$ and the epoxy patch is shown in Figure 3. The glass transition temperature $\left(\mathrm{T}_{\mathrm{g}}\right)$ of the foam patch was measured by thermal mechanical analysis (TMA) at $95^{\circ} \mathrm{C}$.

Table 1: Epoxy Patch Formulation Used for W76 AF\&F Thermal Testing. Ingredient Product Name (Supplier) Amount

\begin{tabular}{lll}
\hline Resin \#1: & Epon 828 (Shell Corp.) & $85 \mathrm{wt} \%$ of resin \\
Resin \#2: & Epon 8121 (Shell Corp.) & $15 \mathrm{wt} \%$ of resin \\
Curing agent: & Epi-cure 3255 (Shell Corp.) & $21.4 \mathrm{phr}$ (parts per \\
Surfactant: & DC-193 (Air Products Corp.) & $1.0 \mathrm{phr}$ \\
Blowing agent: & HCFC-141b (Allied-Signal) & $5.0 \mathrm{phr}$ \\
Nucleating agent: & Cabosil M-7D (Cabot Corp.) & $2.0 \mathrm{phr}$ \\
\hline
\end{tabular}

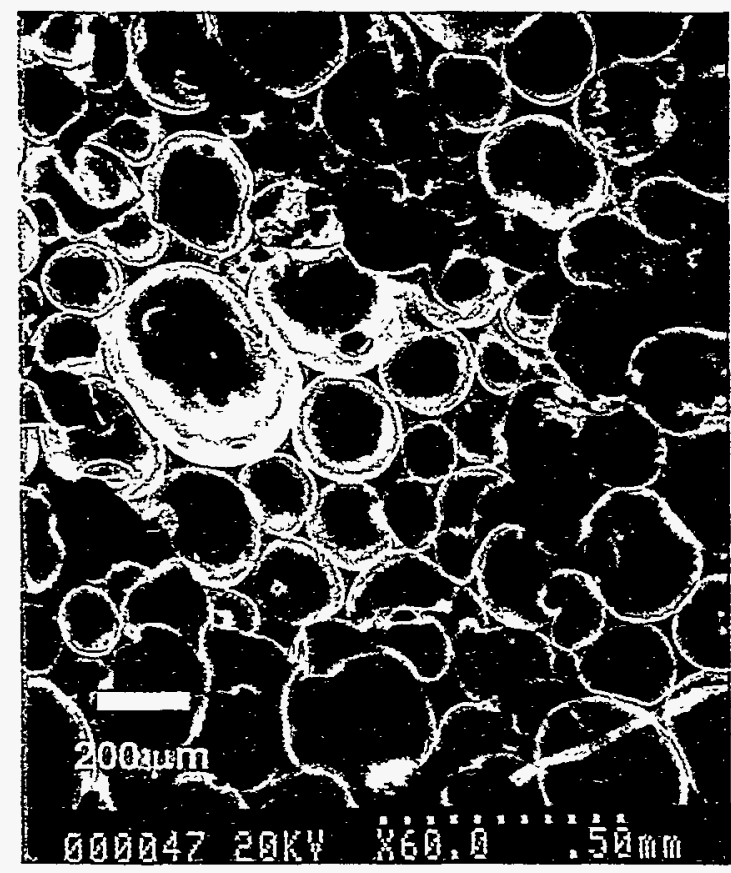

(a)

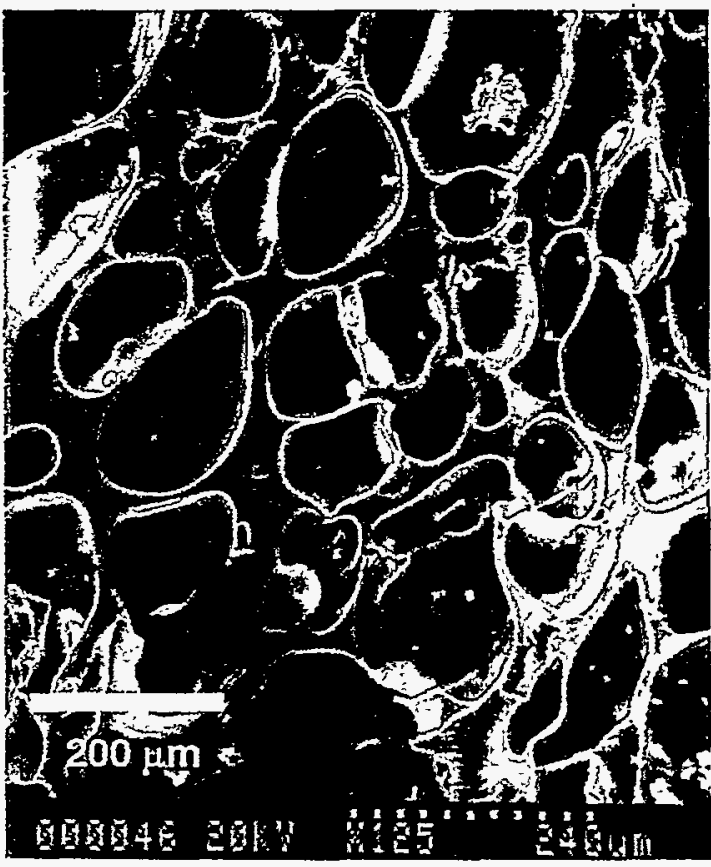

(b)

Figure 3: SEM comparison of Ablefoam ${ }^{\circledR}$ (a) and the new epoxy foam patch (b). 
The W76 AF\&F unit to be patched for thermal testing had a number of circular holes cut from the Ablefoam ${ }^{\oplus}$ encapsulant to allow for thermocouple probes to be attached to various exposed metal surfaces for temperature monitoring. A photograph of the test unit showing the removed portions of Ablefoam ${ }^{8}$ is shown in Figure 4. The volume of each hole cut in the Ablefoam ${ }^{\oplus}$ was measured so that the appropriate amount of epoxy patch mixture could be added to achieve $20 \mathrm{lb} / \mathrm{ft}^{3}$ density. After the thermocouple probes were attached, the epoxy patch formulation was applied to fill the thermocouple access holes. The entire unit was preheated to $70^{\circ} \mathrm{C}$ in a forced convection oven. The preheated unit was removed from the oven, and an appropriate amount of epoxy patch mixture was added to each hole. To keep the foam from expanding out of the void spaces cut in the Ablefoam ${ }^{\circledR}$, thin sheets of metal shim stock were used to cover the holes. Duct tape was used to secure the shim stock to the outer surface of the AF\&F. The thin metal stock was sufficiently flexible to conform to the conical shape of the AF\&F so that the outer surface of expanded foam patch would be flush with the outer surface of the Ablefoam ${ }^{\Theta}$ encapsulant. Several pours of the epoxy patch were required to foam all the holes in the AF\&F due to the number of holes cut on all sides of the unit. After each application of the patch mixture, the unit was replaced in the oven for approximately one hour to allow the expanded foam to cure and harden sufficiently for the AF\&F to be handled. After all holes were patched, the unit was left in the oven for approximately four hours to allow all the foam patches to fully cure. After all the thermocouple access holes were successfully patched, the weapon component successfully underwent radiant heat testing. Thermal data from the testing is currently being analyzed.

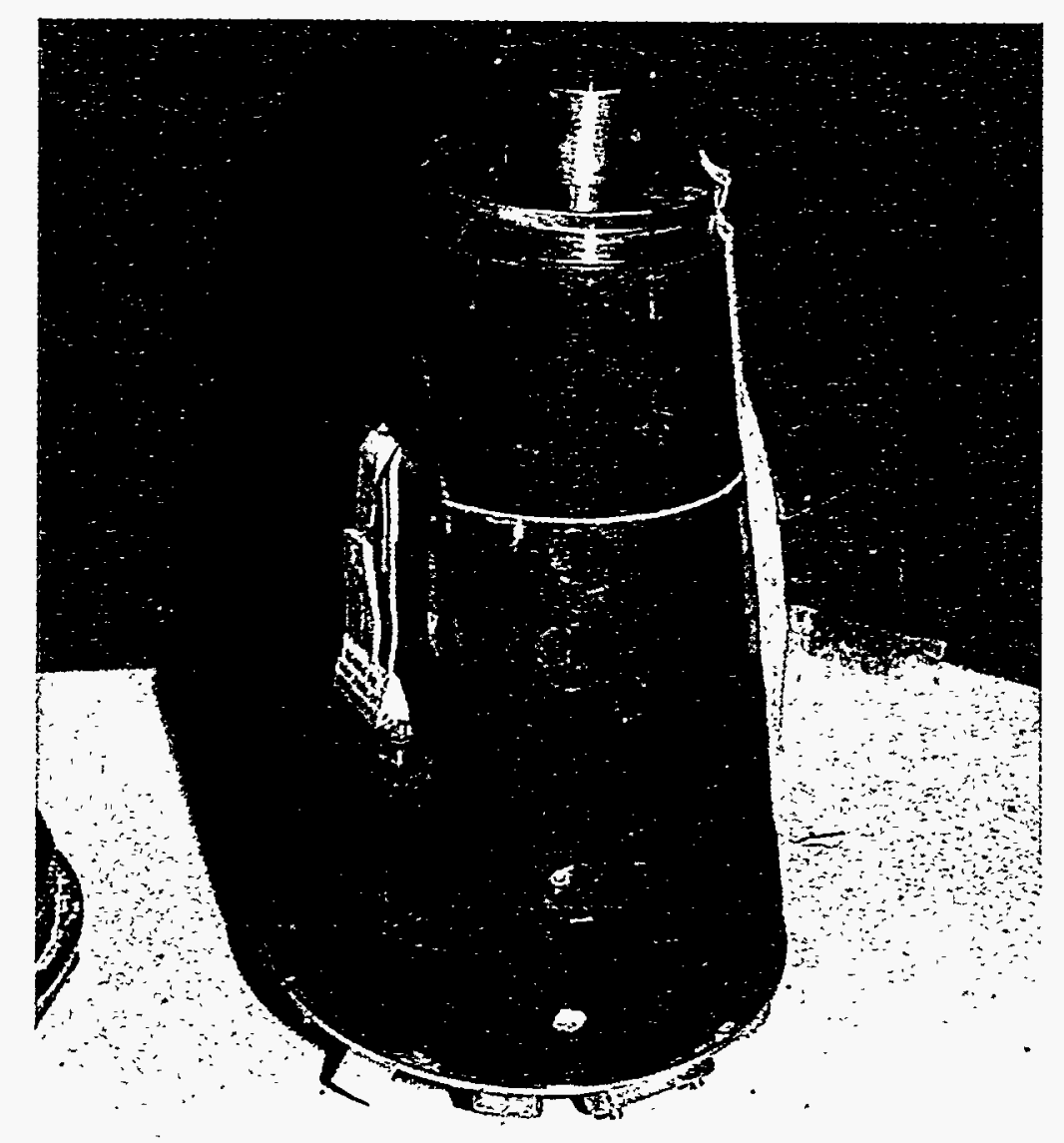

Figure 4: Thermocouple access holes cut in Ablefoam ${ }^{\circledR}$ on the W76 AF\&F. 


\section{Ablefoam $^{\circledast}$ Replacement}

While the epoxy patch formulation was successfully used for the small volume patching application, it is not well suited for large volume applications since it has a very short pot life (i.e., processing time prior to cure). Upon further experimentation with epoxy resins, curing agents, and other ingredient concentrations, epoxy foam devised at a density of $20 \mathrm{lb} / \mathrm{ft}^{3}$ as an Ablefoam ${ }^{\circledR}$ replacement in the W76 AF\&F, and at a density of 10 $\mathrm{lb} / \mathrm{ft}^{3}$. These formulations allows for longer pot life, thus foams of much larger volumes requiring longer rise times can be formed. As with most physically or chemically blown foam systems, slight modifications in the formulation may be required to make large samples with very thick cross-sections. These formulations have been designed with dual resins and dual curing agents so that resin and curing agent ratios may be adjusted to allow for changes in density and sample size. The standard formulation for making epoxy foams at a density of 20 $\mathrm{lb} / \mathrm{ft}^{3}$ (EF-AR20) is shown in Table 2. The formulation for making $10 \mathrm{lb} / \mathrm{ft}^{3}$ epoxy foams (EFAR10) is presented in Table 3.

Table 2: Formulation for Ablefoam ${ }^{\circledR}$ Replacement EF-AR20 ( $\rho=20 \mathrm{lb} / \mathrm{ft}^{3}$ ). Ingredient Product Name (Supplier) Amount

\begin{tabular}{lll}
\hline Resin \#1: & Epon 830 (Shell Corp.) & $60 \mathrm{wt} \%$ of resin \\
Resin \#2: & Epon 8121 (Shell Corp.) & $40 \mathrm{wt} \%$ of resin \\
Curing agent \#1: & Ancamine 2049 (Air Products) & $25.8 \mathrm{phr}$ (parts per \\
Curing agent \#2: & Epi-cure 3270 (Shell Corp.) & $26.2 \mathrm{phr}$ \\
Surfactant: & DC-193 (Air Products Corp.) & $3.0 \mathrm{phr}$ \\
Blowing agent: & FC-72 electronic fluid (3M Corp.) & $6.0 \mathrm{phr}$ \\
Nucleating agent: & Carbon black (Cabot Corp.) & $2.0 \mathrm{phr}$ \\
\hline
\end{tabular}

The epoxy foam process takes place in a mold or other container, preferably metallic, which is suitable for containing the expanding epoxy foam. The mold is preheated in a forced convection oven to a temperature of $65^{\circ} \mathrm{C}$. The resins, surfactant, nucleating agent, and blowing agent are homogeneously mixed together at room temperature in a separate container. Both curing agents are then added and stirred uniformly into the mixture. The viscous liquid mixture is added to the preheated container to be foamed, and the container is sealed. The final density of the foam is determined by the amount of the epoxy mixture that is initially added to the mold prior to foaming. The mold assembly is immediately returned to the forced convection oven set at $65^{\circ} \mathrm{C}$ to cure. When the boiling point $\left(\sim 56^{\circ} \mathrm{C}\right)$ of the $\mathrm{FC}-72$ blowing agent is reached, the vapor evolved causes expansion of the mixture. By this time, the epoxy has cross-linked sufficiently to increase the viscosity of the liquid so as to sustain the newly formed cellular structure. After approximately $4-6$ hours at $65^{\circ} \mathrm{C}$, the foam is fully cured into a rigid, structural foam. 


\begin{tabular}{lll}
$\begin{array}{c}\text { Table 3: Formulation } \\
\text { Ingredient }\end{array}$ & for Ablefoam & \\
& Product Name (Supplier) & Amount \\
\hline Resin \#1: & Epon 830 (Shell Corp.) & $60 \mathrm{wt} \%$ of resin \\
Resin \#2: & Epon 8121 (Shell Corp.) & $40 \mathrm{wt} \%$ of resin \\
Curing agent \#1: & Ancamine 2049 (Air Products) & $25.8 \mathrm{phr}$ (parts per \\
Curing agent \#2: & Epi-cure 3270 (Shell Corp.) & $26.2 \mathrm{phr}$ parts resin) \\
Surfactant: & DC-193 (Air Products Corp.) & $5.0 \mathrm{phr}$ \\
Blowing agent: & FC-72 electronic fluid (3M Corp.) & $15.0 \mathrm{phr}$ \\
Nucleating agent: & Carbon black (Cabot Corp.) & $2.0 \mathrm{phr}$ \\
\hline
\end{tabular}

\section{Foam Properties}

Knowledge of material properties for encapsulants is important in predicting how the material will perform under conditions it may experience in actual use. The foam morphology, as well as mechanical, thermal, and electrical properties of EF-AR10/20 were investigated. Properties data and SEMs for EF-AR10/20 and Ablefoam ${ }^{\circledR}$ were compared. Since Ablefoam ${ }^{\circledR}$ is no longer available, previously collected data ${ }^{2,1,13}$ was obtained from technical reports and memoranda.

\section{Foam Morphology}

An SEM comparison of foam structures for EF-AR10/20 at densities of 10 and $20 \mathrm{lb} / \mathrm{ft}^{3}$ with Ablefoam ${ }^{\ominus}$ at $20 \mathrm{lb} / \mathrm{ft}^{3}$ density is presented in Figure 5. Ablefoam ${ }^{\circledR}$ and EF-AR20 possess very similar foam morphologies with pore sizes in the range of 200-300 $\mu \mathrm{m}$. EF-AR10 also has a pore structure very similar to that of Ablefoam ${ }^{\Theta}$, but with pore sizes in the range of 300$500 \mu \mathrm{m}$. Larger pore sizes are expected at the $10 \mathrm{lb} / \mathrm{ft}^{3}$ density as compared to the $20 \mathrm{lb} / \mathrm{ft}^{3}$ density since approximately half the amount of material expands to fill the same volume. 


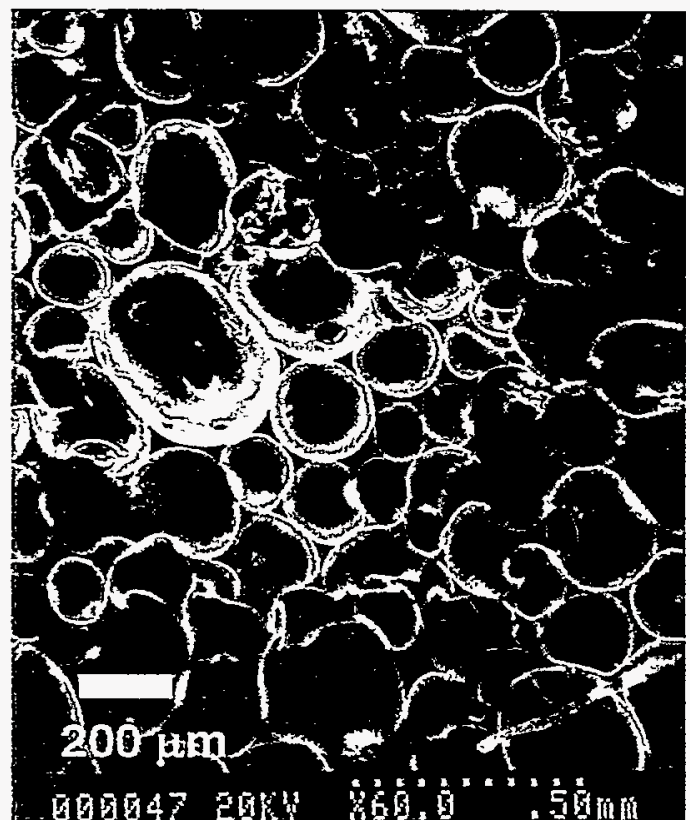

(a)

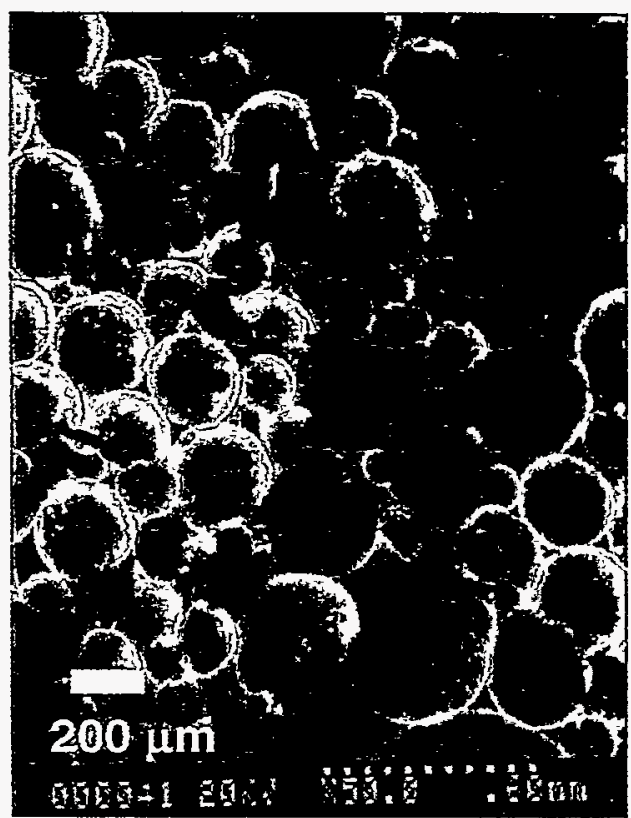

(b)

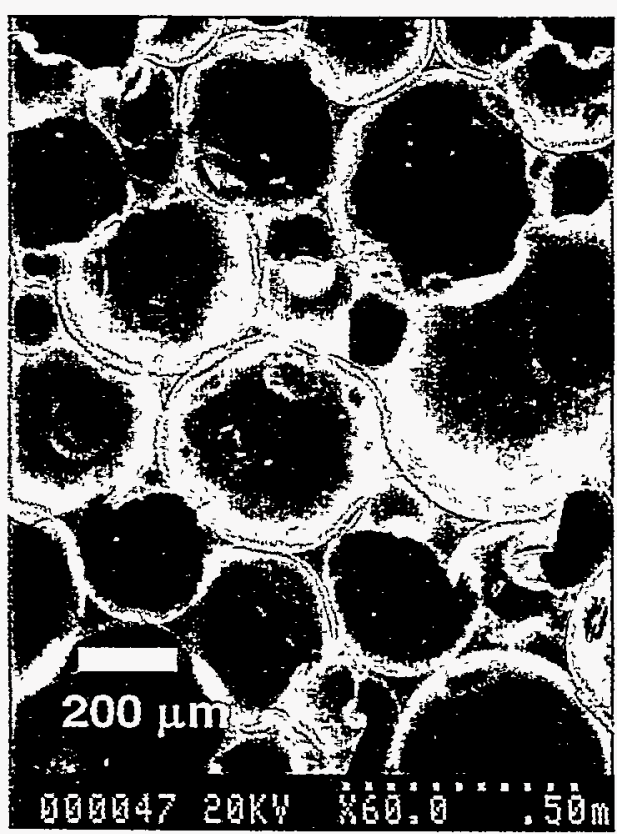

(c)

Figure 5: SEM comparison of $20 \mathrm{lb} / \mathrm{ft}^{3} \mathrm{Ablefoam}^{\oplus}$ (a), EF-AR20 $\left[20 \mathrm{lb} / \mathrm{ft}^{3}\right](\mathrm{b})$, and EF-AR10 $\left[10 \mathrm{lb} / \mathrm{ft}^{3}\right](\mathrm{c})$. 


\section{Compressive Properties}

Compressive strength and compressive modulus of EF-AR10/20 were measured on samples at densities ranging from about 10 to $23 \mathrm{lb} / \mathrm{ft}^{3}$. Foam specimens were 1.129 " OD and 1 "long, which was the sample geometry used with Ablefoam ${ }^{\circledR}$ testing $^{14}$. Compression tests were conducted at room temperature according to ASTM-D-695, "Standard Method for Compressive Properties of Rigid Plastics." Compressive strength and modulus data for EFAR10/20 and available data for Ablefoam ${ }^{\circledR}$ are compared in Table 4. The compressive strength data are graphically compared in Figure 6 . The data demonstrate that EF-AR10/20 possesses higher compressive strength and modulus than does Ablefoam ${ }^{\circledR}$.

\begin{tabular}{|c|c|c|c|c|}
\hline \multirow[b]{3}{*}{$\begin{array}{l}\text { Density } \\
\left(\mathrm{lb} / \mathrm{ft}^{3}\right)\end{array}$} & \multicolumn{4}{|c|}{$\begin{array}{c}\text { Table } 4 \text { Strength and Modulus } \\
\text { of EF-AR10/20 and Ablefoam }{ }^{\Theta} \text {. }\end{array}$} \\
\hline & \multicolumn{2}{|c|}{ EF-AR10/20 } & \multicolumn{2}{|c|}{ Ablefoam } \\
\hline & $\begin{array}{l}\text { Stress at maximum } \\
\text { (psi) }\end{array}$ & $\begin{array}{l}\text { Modulus } \\
\text { (psi) }\end{array}$ & $\begin{array}{l}\text { Stress at maximum } \\
\text { (psi) }\end{array}$ & $\begin{array}{l}\text { Modulus } \\
\quad \text { (psi) }\end{array}$ \\
\hline 10.6 & 299 & 11,922 & & \\
\hline 10.9 & 326 & 13,401 & & \\
\hline 11.4 & 349 & 15,575 & & \\
\hline 11.9 & 381 & 16,791 & & \\
\hline 12.3 & 411 & 18,188 & & \\
\hline 15.0 & & & $545^{*}$ & $18,000 *$ \\
\hline 19.2 & 1,090 & 43,386 & & \\
\hline 19.6 & 1,111 & 44,707 & & \\
\hline 20.0 & & & $1,100 *$ & $42,000 *$ \\
\hline 20.4 & 1,234 & 48,936 & & \\
\hline 22.2 & 1,437 & 56,430 & & \\
\hline 23.2 & 1,571 & 62,352 & $*$ average of & Itiple test \\
\hline
\end{tabular}




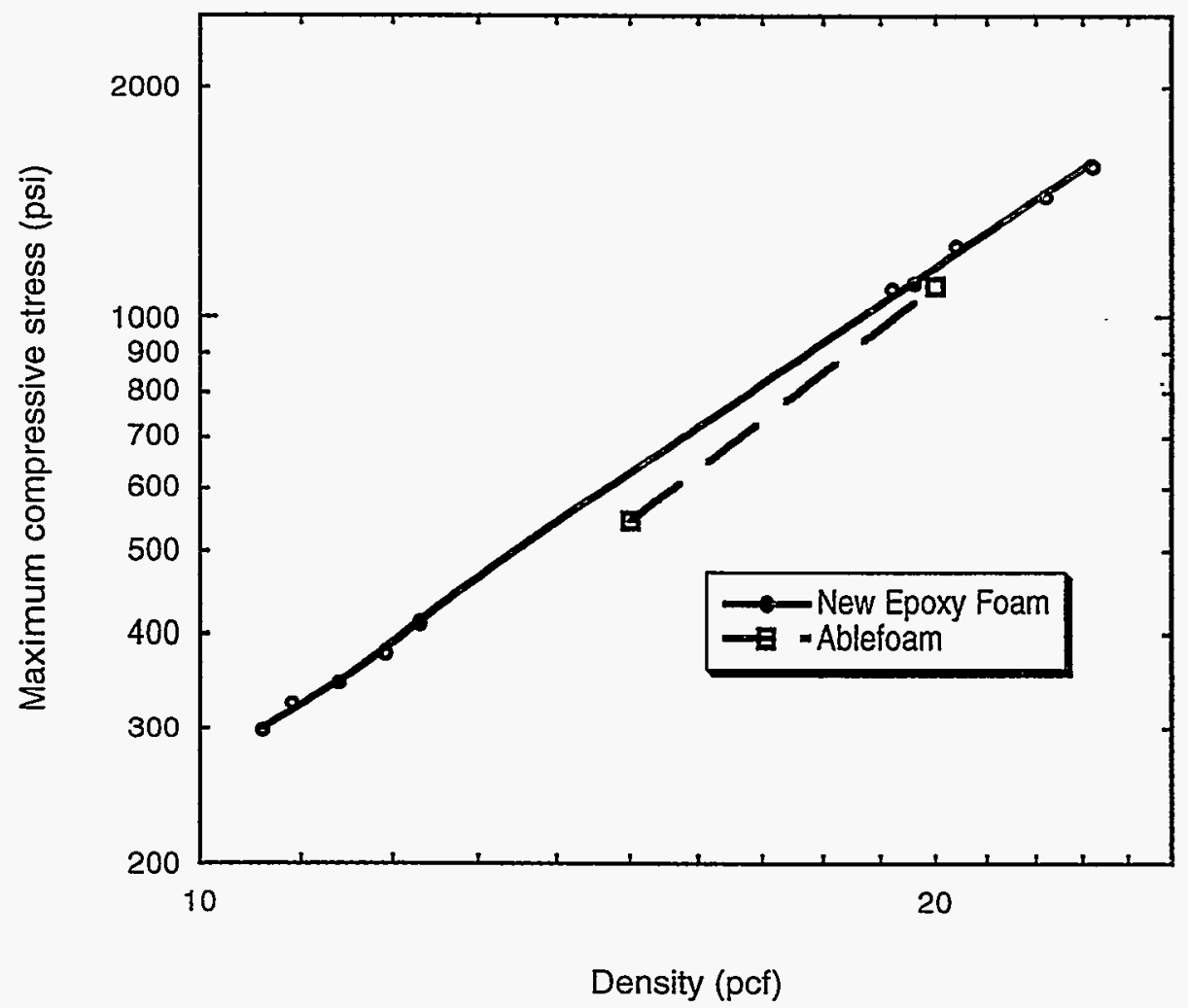

Figure 6: Plot of maximum compressive strength versus density for EF-AR10/20 and Ablefoam.

\section{Tensile Properties}

Ultimate tensile strength and tensile modulus were measured on samples of EFAR10/20 at densities ranging from about 10 to $24 \mathrm{lb} / \mathrm{ft}^{3}$. Tensile specimens were of the same geometry used in compression tests. Tensile testing was conducted at room temperature according to ASTM-D-1623, "Standard Method for Tensile and Tensile Adhesive Properties of Rigid Cellular Plastics." Ultimate tensile strength and modulus data for EF-AR10/20 and available data for Ablefoam ${ }^{\circledR}$ are compared in Table 5. The ultimate tensile strength data are graphically compared in Figure 7. The data indicate that EF-AR10/20 possesses higher ultimate tensile strength and tensile modulus than does Ablefoam ${ }^{\ominus}$. 


\section{Table 5: Ultimate Tensile Strength and Modulus}

of the EF-AR10/20 and Ablefoam ${ }^{\circledR}$.

\begin{tabular}{lcccc}
$\begin{array}{c}\text { Density } \\
\left(\mathrm{lb} / \mathrm{ft}^{3}\right)\end{array}$ & $\begin{array}{c}\text { Stress at Break } \\
(\mathrm{psi})\end{array}$ & $\begin{array}{c}\text { Modulus } \\
(\mathrm{psi})\end{array}$ & $\begin{array}{c}\text { Stress at Break } \\
(\mathrm{psi})\end{array}$ & $\begin{array}{c}\text { Modulus } \\
(\mathrm{psi})\end{array}$ \\
\hline 10.0 & & & $200^{*}$ & $11,500^{*}$ \\
10.6 & 225 & 14,902 & & \\
10.8 & 224 & 14,470 & & \\
11.1 & 250 & 16,841 & & \\
11.7 & 261 & 17,762 & & \\
12.3 & 323 & 19,885 & & \\
19.0 & 604 & 46,077 & & \\
19.6 & 598 & 46,999 & & \\
20.0 & & $500^{*}$ & \\
20.6 & 733 & 57,396 & & \\
21.6 & 912 & 54,401 & & \\
23.2 & 1,050 & 75,325 & &
\end{tabular}

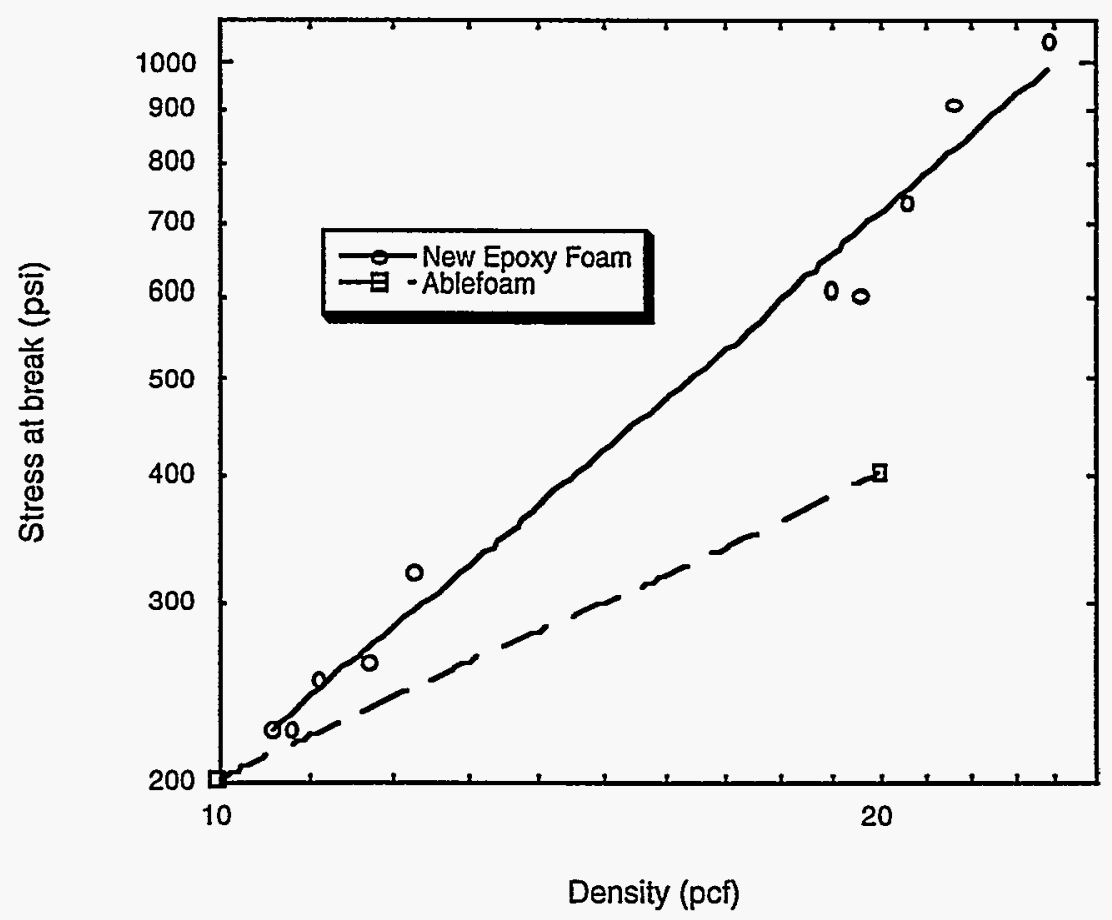

Figure 7: Plot of ultimate tensile strength versus density for EF-AR10/20 and Ablefoam ${ }^{\Theta}$. 


\section{Thermal Properties}

Dynamic mechanical analysis (DMA) and coefficient of thermal expansion (CTE) measurements were performed on EF-AR10/20 at densities of 10 and $20 \mathrm{lb} / \mathrm{ft}^{3}$. The DMA analysis was done to determine the glass transition temperatures $\left(T_{g}\right)$ of the foams, which is the temperature at which the normally rigid, glassy material begins to behave as a rubbery solid. The DMA analysis was performed on 2.25 " $x 0.5$ " $\times 0.25$ " samples. A cyclic torsional force was applied to the samples at a rate of 1 cycle per second while the temperature was ramped from 30 to $110^{\circ} \mathrm{C}$. Shear modulus (G') and loss modulus (G') data was acquired from the DMA with a computer interface. A plot of shear and loss moduli versus temperature for a sample of EF-AR20 is shown in Figure 8. Onset glass transition temperatures were determined from the shear modulus curves. The Tg of EF-AR20 was measured at $89.5^{\circ} \mathrm{C}$. EF-AR10 had a Tg of $84.7^{\circ} \mathrm{C}$. DMA data for Ablefoam ${ }^{\Theta}$ was not available, but for a $20 \mathrm{lb} / \mathrm{ft}^{3}$ sample of Ablefoam ${ }^{\oplus}$, the $\mathrm{T}_{\mathrm{g}}$ was measured at $90.0^{\circ} \mathrm{C}$ by TMA.

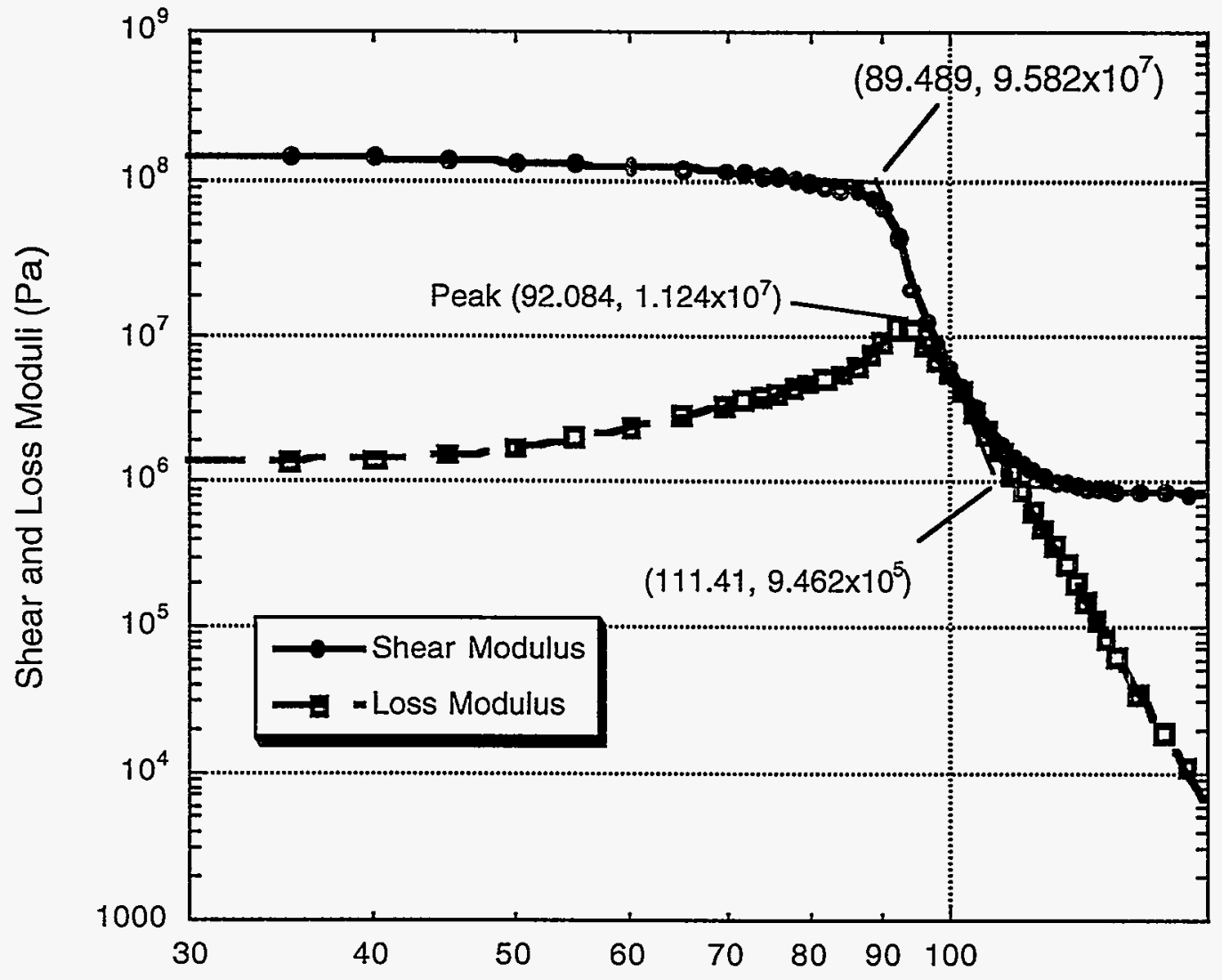

Temperature (C)

Figure 8: Plot of shear and loss modulus versus temperature data for a sample of EF-AR20 $\left(20 \mathrm{lb} / \mathrm{ft}^{3}\right)$. 
Coefficient of thermal expansion (CTE) was measured for EF-AR10/20 at densities of 10 and $20 \mathrm{lb} / \mathrm{ft}^{3}$ using TMA. The CTE measurements were performed on foam samples both parallel and perpendicular to the direction of foam rise. Up to four measurements were made for each foam orientation which were averaged to obtain the reported values. Results of CTE testing are shown in Table 6 . Also included in the table are CTE values for Ablefoam ${ }^{\circledR}$ which were recorded without respect to direction of foam rise. It is clear from the CTE data that regardless of sample orientation, EF-AR10/20 possesses a CTE essentially equal to that of Ablefoam ${ }^{\Theta}$.

\begin{tabular}{|c|c|c|c|}
\hline \multicolumn{4}{|c|}{$\begin{array}{l}\text { Table 6: Coefficient of Thermal Expansion }\left(\times 10^{-6} /{ }^{\circ} \mathrm{C}\right) \\
\text { for EF-AR10/20 and Ablefoam }{ }^{\otimes} .\end{array}$} \\
\hline \multicolumn{2}{|c|}{ EF-AR10/20 } & \multicolumn{2}{|c|}{ Ablefoam } \\
\hline $10 \mathrm{lb} / \mathrm{ft}^{3}$ & $20 \mathrm{lb} / \mathrm{ft}^{3}$ & $10 \mathrm{lb} / \mathrm{ft}^{3}$ & $20 \mathrm{lb} / \mathrm{ft}^{3}$ \\
\hline $61.7^{*}$ & $60.5^{*}$ & 61.0 & 61.2 \\
\hline $61.2^{\#}$ & $62.0^{\#}$ & & \\
\hline
\end{tabular}

\section{Electrical Properties}

While foam encapsulants are generally not utilized in high voltage applications, the material is required to provide resistance to flow of electricity between encapsulated components. The electrical properties of dielectric constant, dissipation factor, and volume resistivity were measured for EF-AR10/20 at densities of 10 and $20 \mathrm{lb} / \mathrm{ft}^{3}$. These data were compared to existing data for Ablefoam ${ }^{\circledR}$.

Dielectric constant, or permittivity, is the measurement of the ability of a material to resist the formation of an electric field within it. Dissipation factor is the measurement of the conversion or loss of electrical power to heat within the material. Dielectric constant and dissipation factor for the new epoxy foam were determined using ASTM-D-150, "Standard Test Methods for AC Loss Characteristics and Permittivity (Dielectric Constant) of Solid Electrical Insulation." Tests were performed at $23^{\circ} \mathrm{C}\left(73.4^{\circ} \mathrm{F}\right)$ and $50 \%$ relative humidity. Samples were disc-shaped with a diameter of 4 inches and thickness of 0.125 inches. Data reported for EF-AR10/20 are the averages of three measurements done on three separate samples. Previously acquired Ablefoam ${ }^{\circledR}$ measurements were performed at $70^{\circ} \mathrm{F}\left(21.1^{\circ} \mathrm{C}\right)$. A comparison of dielectric constants for EF-AR10/20 and Ablefoam ${ }^{\circledR}$ is presented in Table 7. A comparison of dissipation factors EF-AR10/20 and Ablefoam ${ }^{\otimes}$ at the same temperature conditions is shown in Table 8. It is evident from the data that the dielectric constant and dissipation factors for the new epoxy foam are very similar to those of Ablefoam ${ }^{\ominus}$.

Volume resistivity, which indicates the ability of a material to limit current leakage between insulated conductors, was also measured for the new epoxy foam at densities of 10 and $20 \mathrm{lb} / \mathrm{ft}^{3}$. Volume resistivity for the new foam was measured at $23^{\circ} \mathrm{C}\left(73.4^{\circ} \mathrm{F}\right)$ and $50 \%$ relative humidity. Three measurements were averaged to obtain each reported data point. One 
data point was found for $20 \mathrm{lb} / \mathrm{ft}^{3}$ Ablefoam ${ }^{\circledR}$ at approximately the same temperature, $22.2^{\circ} \mathrm{C}$ $\left(72^{\circ} \mathrm{F}\right)$. Table 9 shows a comparison of the volume resistivity data for the EF-AR10/20 and Ablefoam $^{\circledR}$. The data indicate that the volume resistivity of the new epoxy foam is approximately the same as for Ablefoam ${ }^{\circledR}$.

Table 7: Dielectric constants for

EF-AR10/20 and Ablefoam ${ }^{\circledR}$.

EF-ARi0/20

$23^{\circ} \mathrm{C}\left(73.4^{\circ}\right)$
Ablefoam

$21.1^{\circ} \mathrm{C}\left(70^{\circ} \mathrm{F}\right)$

\begin{tabular}{cllll}
\hline $\begin{array}{c}\text { Frequency } \\
60 \mathrm{~Hz}\end{array}$ & $10 \mathrm{lb} / \mathrm{ft}^{3}$ & $20 \mathrm{lb} / \mathrm{ft}^{3}$ & $10 \mathrm{lb} / \mathrm{ft}^{3}$ & $20 \mathrm{lb} / \mathrm{ft}^{3}$ \\
$10^{2} \mathrm{~Hz}$ & 1.41 & 1.75 & & \\
$10^{5} \mathrm{~Hz}$ & 1.36 & 1.73 & 1.5 & 1.8 \\
$10^{6} \mathrm{~Hz}$ & 1.29 & 1.62 & 1.4 & 1.6 \\
$10^{7} \mathrm{~Hz}$ & & & 1.4 & \\
\hline
\end{tabular}

Table 8: Dissipation factors for EF-AR10/20 and Ablefoam ${ }^{\circledR}$.

EF-AR10/20

$23^{\circ} \mathrm{C}\left(73.4^{\circ} \mathrm{F}\right)$
Ablefoam

$21.1^{\circ} \mathrm{C}\left(7^{\circ} \mathrm{F}\right)$

\begin{tabular}{cllll}
\hline Frequency & $10 \mathrm{lb} / \mathrm{ft}^{3}$ & $20 \mathrm{lb} / \mathrm{ft}^{3}$ & $10 \mathrm{lb} / \mathrm{ft}^{3}$ & $20 \mathrm{lb} / \mathrm{ft}^{3}$ \\
$60 \mathrm{~Hz}$ & 0.055 & 0.029 & & \\
$10^{2} \mathrm{~Hz}$ & 0.035 & 0.024 & 0.011 & 0.020 \\
$10^{5} \mathrm{~Hz}$ & & & 0.011 & \\
$10^{6} \mathrm{~Hz}$ & 0.010 & 0.011 & & 0.023 \\
$10^{7} \mathrm{~Hz}$ & & & 0.010 & \\
\hline
\end{tabular}




\begin{tabular}{|c|c|c|c|}
\hline \multirow[b]{3}{*}{ Voltage } & \multicolumn{3}{|c|}{$\begin{array}{l}\text { Table 9: Volume resistivity (ohm-cm) data for } \\
\text { EF-AR10/20 and Ablefoam }{ }^{\circledR} \text {. }\end{array}$} \\
\hline & \multicolumn{2}{|c|}{$\begin{array}{c}\mathrm{EF}-\mathrm{AR} 10 / 20 \\
23^{\circ} \mathrm{C}\left(73.4^{\circ} \mathrm{F}\right)\end{array}$} & \multirow{2}{*}{$\begin{array}{c}\text { Ablefoam } \\
22.2^{\circ} \mathrm{C}\left(7^{\circ} \mathrm{F}\right) \\
20 \mathrm{lb} / \mathrm{ft}^{3}\end{array}$} \\
\hline & $10 \mathrm{lb} / \mathrm{ft}^{3}$ & $20 \mathrm{lb} / \mathrm{ft}^{3}$ & \\
\hline $500 \mathrm{~V}$ & $1.029 \mathrm{E}+13$ & $2.596 \mathrm{E}+13$ & $2.512 E+13$ \\
\hline $1000 \mathrm{~V}$ & $7.748 \mathrm{E}+12$ & $2.166 \mathrm{E}+13$ & \\
\hline
\end{tabular}

Initial experiments were performed to measure the dielectric breakdown strength of EFAR20. The dielectric breakdown strength is an indication of the electrical strength of the material as an insulator. The dielectric strength is the voltage at which electrical failure or breakdown occurs as a continuous arc within the insulating material. Dielectric breakdown samples were prepared by potting sets of two spherical electrodes with $20 \mathrm{lb} / \mathrm{ft}^{3}$ epoxy foam. Spacing between the electrodes was varied from 1 to $4.2 \mathrm{~mm}$. A single pulse direct current (DC) voltage was applied and increased until electrical breakdown occurred in the foam between the electrodes. From several preliminary breakdown experiments, the average dielectric breakdown strength for EF-AR20 was $23,800 \mathrm{~V}(23.8 \mathrm{kV}) / \mathrm{mm}$. No dielectric strength data has been found for Ablefoam ${ }^{\circledR}$. In the future, additional measurements would be required to verify the accuracy of these initial experiments for the $20 \mathrm{lb} / \mathrm{ft}^{3}$ foam, and measurements would be done on EF-AR10.

\section{W76 AF\&F Redesign}

New epoxy foam material was requested by Randy Harrison of the Advanced Weapons Projects Department at SNL so that a prototype of the new W76 AF\&F design could be assembled. While Ablefoam ${ }^{\circledR}$ could be cast to a thickness no greater than 1 inch due to burn out from internal heat generation while curing, the new epoxy foam was successfully cast in 7 inch diameter by 8 inch long cylinders at a density of $20 \mathrm{lb} / \mathrm{ft}^{3}$. EF-AR20 was found to be very machinable, and foam piece parts for the new W76 AF\&F prototype were successfully machined and assembled. Photographs of two of the machined epoxy foam parts for the new W76 AF\&F prototype are shown in Figure 9. 

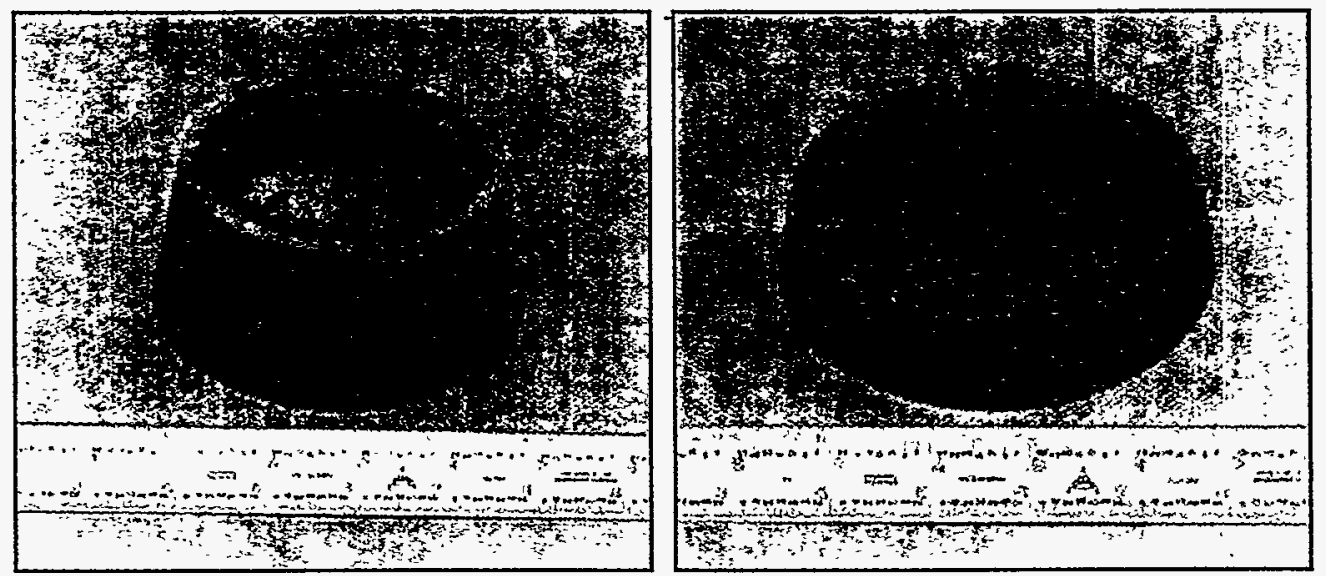

Figure 9: Parts machined from EF-AR20

for a prototype of the new W76 AF\&F design.

\section{Conclusions}

Ablefoam $^{\circledR}$, a rigid epoxy foam, was the encapsulant used in the W76 arming, fusing, and firing $(\mathrm{AF} \& \mathrm{~F})$ system. A redesign of the W76 AF\&F, a part of the block upgrade program, is underway which would allow for maintenance, repair, and upgrading of components in the unit. Since Ablefoam ${ }^{\circledR}$ is no longer commercially available primarily due to toxicity concerns, a replacement foam encapsulant is required for the new W76 AF\&F redesign.

A new epoxy foam encapsulant, EF-AR10/20, has been developed at Sandia National Laboratories as a replacement for Ablefoam ${ }^{\circledR}$ in the W76 AF\&F. It has been demonstrated that the microstructure of EF-AR10/20 is similar to that of Ablefoam ${ }^{\circledR}$. Mechanical, thermal, and electrical properties of the new foam have been measured and compared to previously. measured properties of Ablefoam ${ }^{\circledR}$. EF-AR10/20 has been shown to possess properties, which are comparable to or exceed those of Ablefoam ${ }^{\circledR}$. Machined epoxy foam parts have been fabricated for a prototype of the new W76 AF\&F design. Efforts are underway to have the new epoxy foam qualified for actual use in the enduring weapons stockpile.

\section{Acknowledgements}

Mechanical and thermal property measurements of the new epoxy foam were conducted by Mark Stavig at Sandia National Laboratories. Dielectric constant, dissipation factor, and volume resistivity of the new foam were measured by Plastics Technology Laboratories, Inc., Pittsfield, MA. Dielectric breakdown strength measurements were coordinated by John Schroeder and performed by Greg Hassig at SNL.

Sandia is a multiprogram laboratory operated by Sandia Corporation, a Lockheed Martin Company, for the United States Department of Energy under Contract DE-AC0494AL85000. 


\section{References}

1. L. J. Gibson and M. F. Ashby, "Cellular Solids: Structure and Properties," 2nd edition (Cambridge Univ. Press: Cambridge, UK, 1997).

2. C. C. Thacker, Sandia Report, Sandia National Laboratories, SC-DR-68-778 (November 1968).

3. P. A. Dunn, T. J. Williams, and J. A. Sayre, Sandia Report, Sandia National Laboratories, SAND93-1085 (February, 1994).

4. D. Klempner and K. C. Frisch, "Handbook of Polymeric Foams and Foam Technology," (Hanser: Munich, 1991).

5. K. C. Frisch and J. H. Saunders, "Plastic Foams, Part II," (Marcell Dekker: New York, 1973).

6. H. Lee, and K. Neville, "Epoxy Resins: Their Applications and Technology," (McGraw-Hill, New York, 1957).

7. T. H. Ferrigno, "Rigid Plastic Foams," (Reinhold: New York, 1967).

8. E. W. Flick, "Epoxy Resins, Curing Agents, Compounds, and Modifiers: An Industrial Guide," 2nd edition, (Noyes Publications: Park Ridge, NJ, 1993).

9. H. F. Mark, et. al. Eds., "Encyclopedia of Polymer Science and Engineering," 2nd edition, Vol. 2, (John Wiley \& Sons: New York, 1985).

10. C. J. Benning, "Plastic Foams: The Physics and Chemistry of Product Performance and Process Technology," (Wiley-Interscience: New York,1969).

11. C. E. Brennan, "Cavitation and Bubble Dynamics" (Oxford Univ. Press: New York, 1995).

12. J. G. Curro, Sandia Laboratories memo to R. D. Christopher, December 10, 1979.

2 P. B. Rand, Sandia Laboratories memo to J. S. Souza, May 17, 1982. 


\section{DISTRIBUTION:}

2 Allied Signal, Inc.

Federal Manufacturing \& Technologies Division (FM\&T)

Attn: Patricia Wilson

David Spieker

P.O. Box 419159

Kansas City, MO 64141-6159

$\begin{array}{lrl}1 & \text { MS } 1407 & \text { J. H. Aubert, 1815 } \\ 1 & 0367 & \text { R. S. Saunders, 1815 } \\ 1 & 0367 & \text { P. B. Rand, 1815 } \\ 15 & 0367 & \text { E. M. Russick, 1815 } \\ 1 & 1407 & \text { T. A. Ulibarri } \\ 1 & 1435 & \text { A. K. Hays, 1800 } \\ 1 & 0958 & \text { M. E. Stavig, 1472 } \\ 1 & 0958 & \text { H. W. Arris, 1472 } \\ 1 & 0958 & \text { M. W. Donnelly, 1472 } \\ 1 & 0958 & \text { R. L. Myers, 1472 } \\ 1 & 0958 & \text { C. L. J. Adkins, 1472 } \\ 1 & 0961 & \text { J. A. Sayre, 1403 } \\ 1 & 0481 & \text { R. J. Harrison, } \\ 1 & 0481 & \text { M. W. Moulton, 2167 } \\ 1 & 0481 & \text { M. A. Rosenthal, 2167 } \\ 1 & 0501 & \text { P. G. Stromberg, 2334 } \\ 1 & 0501 & \text { G. R. Laguna, 2338 } \\ 1 & 0505 & \text { P. E. Pierce, 2336 } \\ 1 & 0537 & \text { J. A. Dye, 2314 } \\ 1 & 9018 & \text { Central Technical Files, 8940-2 } \\ 2 & 0899 & \text { Technical Library, 4916 } \\ 1 & 0619 & \text { Review \& Approval Desk, 15102 } \\ & & \text { For DOE/OSTI } \\ 1 & 0161 & \text { Patent \& Licensing Office, 11500 }\end{array}$

